\title{
Review
}

\section{Routledge handbook of psychoanalytic political theory}

\author{
Yannis Stavrakakis (ed.) \\ Routledge, London and New York, 2020, 464pp., \\ ISBN: 978-1-138-69631-o
}

Contemporary Political Theory (2022) 21, 159-164. https://doi.org/10.1057/s41296021-00471-3; Published online 23 February 2021

The Routledge Handbook of Psychoanalytic Political Theory, edited by Yannis Stavrakakis, is an impressive collection of essays that showcase various ways that socio-political phenomena can be approached through a psychoanalytic lens. But as with all good interdisciplinary projects, fascinating questions arise. Dany Nobus, in his chapter 'Psychoanalytic Geopolitics', captures one such question. He wonders whether psychoanalysis can only thrive in democratic societies, where autonomy, self-governance, and freedom of speech are unrestricted. His answer is that psychoanalysis is more flexible as a field than commonly assumed, and that its adoption and sustainability in non-democratic societies depends largely on the ways it is developed. Nobus tells us that there is space to develop psychoanalysis (p. 364), as there is space to use the many registers of psychoanalytic theorising to interpret socio-political configurations. For psychoanalysis is versatile enough to produce insights that enrich and expand political analysis - or so the contributors to the collection argue. This is the claim that holds the collection together, prompting the reader to ponder the import of the confluence between psychoanalysis and politics.

Of course, staging encounters between psychoanalysis and politics is not new. Critical theorists throughout the twentieth century, from the Frankfurt School's pessimistic diagnoses of the future of civilisation to post-structuralist accounts of the place of identity and difference in politics, have turned to psychoanalysis to reflect on cultural, social, and political situations challenging the norms, instincts, and rationalities stored in hegemonic motifs of human nature. And there are other, more contemporary, works that intelligently use psychoanalysis to interpret political phenomena (e.g. McAffee, 2019). But what is remarkable, and indeed distinctive, about this collection, is that it carves out a space for psychoanalytic political theory as a specific orientation in political studies. This is a thoughtprovoking, and, as I will suggest, significant endeavour for any theorist dissatisfied

(C) 2021 The Author(s), under exclusive licence to Springer Nature Limited part of Springer Nature. 14708914 Contemporary Political Theory Vol. 21, S4, S159-S164 www.palgrave.com/journals 
with the many iterations of liberal political theory. But it is also a difficult undertaking.

A taste of these difficulties should already be apparent: psychoanalysis, understood as the clinical science of the mind, a field that largely draws on clinical experience, is too centred on the (western) individual instead of the collective entities of states and citizens on which political analysis invariably draws. At the same time, psychoanalytic theories of sexuality, the unconscious, and desire transpire as too insular and perhaps even too reductionist to generate relevant, let alone useful, explanations of the changing realities with which political theorists are typically concerned: the nature of justice, power, or the legitimacy of the state. And they are also perhaps too esoteric to attract readers unfamiliar with the often technical jargon psychoanalytic theories deploy to capture human experience. From this perspective, one might wonder whether the difficulties outweigh the benefits that psychoanalysis brings to politics and, more specifically, political theory. But this would be a rushed conclusion.

Various chapters in the collection impressively confront and debate these kinds of difficulties. For example, the chapters in the section 'Themes' explain how psychoanalysis can help us understand phenomena with troubling political implications by clarifying the psychoanalytic concepts they deploy. Samo Tomšič's chapter on capitalism is exemplary in this respect. It unpacks the Freudo-Lacanian account of the unconscious with wonderful clarity to illustrate how it can serve as the basis for a critique of capitalism. The unconscious, Tomšič explains, already 'depends on social links or modes of production' (p. 297). It contains the experiences of subjects and stores damages like traumas and neuroses that capitalism overproduces (p. 300). Therefore, a glimpse into its operation allows us not only to examine the connection between capitalism and subjectivity but also to use the Freudo-Lacanian critique of its libidinal economy as a supplement to Marxist critique.

Along similar lines, Derek Hook's chapter on racism does a good job of explaining the Lacanian concept of jouissance with the aim of understanding what fuels racism. Hook is wary of the decontextualisation and psychological reductionism that are recurring tendencies in psychologisations of racist actions. But he suggests that the idea of racist 'enjoyment' (or jouissance), which is both social and individual, can help us recognize and connect the affective dimension of racism with the socio-historical context that psychologisations of racism often miss. Amanda Machin's chapter on nationalism does something similar by shedding light on processes of affective identification showing how various psychoanalytic accounts offer an invaluable framework for understanding 'the dark side of nationalism' (p. 286) and the potency of nationalist identifications.

In a nutshell, this is not a book aimed only at the already converted, even though the converted will not be disappointed. Its strength is precisely that it reaches out to theorists unfamiliar with psychoanalysis and its vocabulary. The general structure 
of the book helps in this respect. Neatly divided into sections that take the reader on a journey into the dominant traditions, figures, concepts, themes, and controversies of psychoanalytic political theory, the book provides a succinct overview of the debates within psychoanalysis and highlights the critical resources that it brings to the study of politics.

After all, the aim of the book is 'to enrich and reorient (political) theory by employing psychoanalytic concepts, theoretical strategies and analytical methods in mapping, accounting and interpreting socio-political phenomena' (p. 1). For this reason, confronting the difficulties hovering over the confluence between politics and psychoanalysis is not only important but also key to realizing the aim of carving out a space for psychoanalytic political theory. To appreciate the importance of this intervention, one has to keep in mind that the confluence between these two fields is not seamless. While politics and psychoanalysis share sufficient common ground to be put into conversation, this conversation is not without tensions. These tensions revolve around the fields' different sensibilities, directionalities, and, methods. Yet they are productive tensions, according to Stavrakakis. Moreover, they open the way to cross-fertilisation between ideas and approaches that proceed from different lines of enquiry.

Take, for instance, the theme of subjectivity. Theorists of both politics and psychoanalysis maintain a strong interest in subjectivity to explain, among other things, the influence it exerts on political activity (theorists of politics) or to interpret and name its desires, fears, or acts (theorists of psychoanalysis). An encounter between the two approaches, as some of the contributors vividly demonstrate, generates insights into the causes and effects of socio-political actions or phenomena that give a different, psychoanalytically influenced spin to our understanding of subjectivation. This example points to a slightly different way that psychoanalysis might productively interact with politics: by giving rise to distinctive approaches to particular phenomena that incorporate concepts or strategies stemming from psychoanalytic experience, rather than seeking to directly interpret the phenomena in question through a psychoanalytic lens.

Paula Biglieri and Gloria Perelló's chapter on populism productively uses the work of Ernesto Laclau to illustrate how the Lacanian inspiration underpinning his account of populism and his particular focus on the logics of difference/equivalence yield an innovative, and indeed radical, account of politics. Similarly, Campbell Jones focuses on collective subjects against the backdrop of capitalism, and particularly on the movement from the individual to the subject that psychoanalysis conceptualises. Jones is not exactly interested in how psychoanalysis might help us grasp capitalist relations of production. Instead, he grounds his approach on psychoanalytic accounts of collective subjectivity, showing how 'the repression of the reality and possibility of collective economic and social life are part and parcel of the development of capitalist ideology' (p. 244). Coupled with other compelling chapters in the section Concepts - especially the chapters on mourning and

(c) 2021 The Author(s), under exclusive licence to Springer Nature Limited part of Springer Nature. 1470- S161 8914 Contemporary Political Theory Vol. 21, S4, S159-S164 
melancholia, fantasy, trauma, identification with the aggressor, and the superego and the law - Jones' work appeals to readers who look to expand (rather than begin) their reading journey through psychoanalytic concepts.

If politics is hospitable to psychoanalysis and psychoanalysis, in turn, is already political and oriented towards the social bond, then the question shifts from matters of compatibility to navigation. Put differently, when the task of carving out and registering psychoanalytic political theory as a particular area of enquiry is characterized by difficulties and tensions, the question is how we might begin to work around them.

Several of the contributors to the collection claim that they use the psychoanalytic method to interpret political phenomena. This method entails, first, an examination of phenomena that tend to resist comprehension, and second, a reflection on the emergence of socio-political formations from an angle that either escapes dominant theories or is simply unavailable in conventional - especially liberal - political theorising. Third, the method involves an attempt to expand and extend dominant accounts of identifiable phenomena, such as posthumanism or immigration in the section 'Challenges and controversies', by using psychoanalysis. Therefore, extraction of those aspects of a phenomenon that appear irrational, uncovering that which is hidden from view, and theoretical expansion can be tentatively set apart as tools at the hand of the theorist who deploys the psychoanalytic method to engage with political phenomena. Do these tools sit easily with political theory?

Political theory in its many traditions, approaches and styles is no stranger to questions of method, but it is not particularly comfortable with systematic categorisations of its forms and modes of enquiry. There is, of course, discussion of ideal theory following the work of Rawls (1971), of normative theory in accounts of deliberative democracy inspired by critical theory, and particularly by the work of Habermas (1997), of redescription in the work of Tully (2008), and of political realism, for instance in the work of Mouffe (2000) or Green (2011), to name just a few.

However, what strikes me in the collection is the contrast between the mode of enquiry that one arguably discerns in work on political theory, broadly understood here as a field concerned with the meaning and practice of politics, and the deployment of the psychoanalytic method to theorise political phenomena, which tends to jettison the strengths of political theory. The overt focus of the chapters on the explanation of the benefits of psychoanalytic concepts for the study of politics, particularly of phenomena that are overlooked or resist theorisation, comes at the expense of the kind of rigorous conceptual analysis, tight argumentation, and critique distinctive of political theory. Perhaps this is a problem with all handbooks, even more so with bold collections that stage encounters between two fields. Or maybe it is a manifestation of the very tension between psychoanalysis and political theory that Stavrakakis brings to our attention. Rather than suggesting that

S162 (c) 2021 The Author(s), under exclusive licence to Springer Nature Limited part of Springer Nature. 14708914 Contemporary Political Theory Vol. 21, S4, S159-S164 
this tension ends up undermining the merits of the collection, I think that it invites further reflection, not just about the aims of political theory, but also about whether political theorists should take questions of method, including the psychoanalytic method, more seriously.

By pressing forward such reflection, the collection is certain to set political theory that takes up its insights on a radical path. The significance of the collection is that it establishes psychoanalytic political theory as a distinctive area of analysis whose productive potential lies precisely in its tensions, frictions, and ruptures. Stavrakakis, in his introduction to the collection, identifies disruption as the common denominator of politics and psychoanalysis, arguing that much like the political, the unconscious formations that psychoanalysis studies (such as slips of the tongue, symptoms, etc.) 'disrupt our "normal", conscious, mental functioning, and they dislocate social interaction and naturalised political processes' (p. 5).

The radical possibilities of this disruption are many. The one I want to conclude, here, with is the following: if equality, rights, citizens, and political legitimacy, to name just a few of the concerns shared by political theorists, constitute dynamic fields of analysis within political theory, and if liberal theorising is the hegemonic lens through which these themes are viewed, the space for other ways of doing political theory is significantly circumscribed. One might rightly point out that liberal theory does not exhaust the field of enquiry, with critical theory, feminist theory, green political theory and other approaches securely established. While psychoanalytic political theory might be included in this list, I want to suggest that it lays the groundwork for something more in relation to liberal thought by exposing the limits of liberal explanations of politics. By virtue of its externality its focus on other scenes, such as narcissism, the super-ego, aggression, trauma, or mourning - and other sites of political causality, psychoanalytic political theory challenges settled assumptions and interpretations of socio-political configurations. It thereby enables another way of doing political theory.

When we consider the disruptions of tradition and conventional accounts that this other way of political theorising involves, it is no exaggeration to suggest that psychoanalysis radicalises political theory by opening up and reworking the interpretations and analyses political theorists offer. For this reason, political theory needs psychoanalysis, and Psychoanalytic Political Theory offers a good starting point for meeting this need.

\section{References}

Green, J. E. (2011). The eyes of the people: Democracy in an age of spectatorship. New York: Oxford University Press.

Habermas, J. (1997). Between facts and norms. Cambridge: Polity Press.

(c) 2021 The Author(s), under exclusive licence to Springer Nature Limited part of Springer Nature. 1470- S163 8914 Contemporary Political Theory Vol. 21, S4, S159-S164 
McAffee, N. (2019). Fear of breakdown: Politics and psychoanalysis. New York: Columbia University Press.

Mouffe, C. (2000). The democratic paradox. London: Verso.

Rawls, J. (1971). A theory of justice. Cambridge, Mass.: Harvard University Press.

Tully, J. (2008). Public philosophy in a new key, volume I: Democracy and civic freedom. Cambridge: Cambridge University Press.

Publisher's Note Springer Nature remains neutral with regard to jurisdictional claims in published maps and institutional affiliations.

Paulina Tambakaki University of Westminster, London W1T 3UW, UK tambakp@westminster.ac.uk 